\title{
EFEKTIFITAS MODEL PEMBELAJARAN KOOPERATIF TIPE TAI (TEAMS ASSITED INDIVIDUALIZATION) TERHADAP HASIL BELAJAR MATERI HIMPUNAN PADA SISWA SMP MARIA MEDIATRIX AMBON
}

\author{
Maria Ngilamele ${ }^{1}$, Christina M. Laamena ${ }^{2}$, Anderson Palinussa ${ }^{3}$ \\ Pendidikan Matematika Universitas Pattimura ${ }^{1,2,3}$
}

Email: christinmath18@gmail.com

\begin{abstract}
This study aims to determine the effectiveness of the cooperative learning type TAI (Teams Assisted Individualization) model according to the results of junior high school mathematics learning in material of set. The method used was quasi-experimental with the post-test only given to control group chosen taking design. Samples were taken using a purposive sampling technique, and two classes by considering students' initial abilities. The control class was treated by using conventional models while the experimental class uses the TAI type cooperative learning model. Data were analyzed by t-test technique. This study revealed that the learning outcomes of students who studied with the cooperative learning model type TAI (67.75) were higher compared to conventional learning models (54.45). Testing the significance of differences with the $\mathrm{t}$-test shows that $\mathrm{t}$ count $=2.206>\mathrm{t}$ table $=2.024$, meaning that there are significant differences between the two groups. It can be concluded that the TAI model is more effective as it is reflected on students' higher scores compared to those who were treated with conventional models.
\end{abstract}

Keywords: learning outcome, cooperative model, team assisted individualization.

\section{PENDAHULUAN}

Matematika merupakan salah satu mata pelajaran yang diajarkan di semua jenjang pendidikan baik SD, SMP maupun SMA dengan jumlah jam pelajaran yang lebih banyak dibandingkan dengan mata pelajaran lainnya. Secara teoritik, matematika adalah ilmu yang bertujuan mendidik manusia agar dapat berpikir logis, kritis, rasional dan percaya diri sehingga mampu membentuk kepribadian yang mandiri, kreatif serta mempunyai kemampuan dan keberanian dalam menghadapi masalah dalam kehidupan sehari-hari. Matematika kaya akan konsep yang saling berhubungan dan tersusun secara hierarki. Artinya, setiap konsep dalam matematika berkaitan dengan konsep lainnya sehingga penguasaan konsep dasar merupakan hal wajib yang harus dimiliki siswa jika ingin 
berhasil dalam memahami konsep lainnya.

Salah satu konsep dasar penting yang harus dikuasai siswa adalah konsep himpunan. Materi himpunan dipelajari pada jenjang SMP dan akan dilanjutkan di jenjang SMA dengan materi yang lebih kompleks. Oleh karena itu penguasaan konsep himpunan yang baik di SMP akan menolong siswa untuk menguasai konsep himpunan di SMA.

Namun beberapa hasil penelitian (Adilistiyo, 2017; Pratiwi, 2016; Arfiyanti, Irawan, Purwanto, 2017; Khairul, 2018) menunjukkan bahwa masih banyak siswa yang mengalami kesulitan dalam mempelajari materi himpunan. Menurut Khairul (2018) dan Adilistiyo (2017), terdapat beberapa kesulitan siswa SMP yang berkaitan dengan materi himpunan dan operasinya, diantaranya:

1. Siswa sukar mengubah bahasa soal menjadi simbol-simbol matematika tentang himpunan

2. Pola pikir siswa yang menganggap simbol matematika itu rumit, sehingga siswa kesulitan mengartikan simbol matematika dan tidak dapat menemukan kata kunci dari soal

3. Rendahnya pemahaman siswa dalam menalar dan memahami soal materi himpunan

4. Kurangnya ketelitian dalam menyelesaikan operasi hitung karena langkahlangkah pengerjaan yang kurang sistematis.

Masalah yang hampir sama juga ditemukan peneliti ketika observasi pada SMP Maria Mediatrix Ambon, diantaranya: sebagian besar siswa masih sukar membedakan himpunan dan bukan himpunan; siswa sukar menentukan hasil operasi penjumlahan dan pengurangan pada himpunan; dan siswa sukar menyelesaikan soal cerita yang berkaitan dengan himpunan. Semua ini berdampak pada hasil belajar matematika, khusus pada materi himpunan yang masih sangat rendah.

Cara mengajar guru dapat mempengaruhi pengetahuan siswa tentang konsep himpunan dan operasinya. Artinya, model pembelajaran yang digunakan guru sangat menentukan penguasaan siswa. Hal senada disampaikan oleh Ratumanan (2015) bahwa pembelajaran matematika saat ini kurang memberikan perhatian pada aktivitas siswa. Guru terlalu mendominasi kegiatan belajar mengajar, guru bahkan ditempatkan sebagai sumber utama pengetahuan dan berfungsi sebagai pentransfer pengetahuan. Sebaliknya siswa lebih banyak pasif, diposisikan sebagai objek belajar, dikondisikan hanya untuk 
menunggu proses transformasi pengetahuan dari guru sehingga guru lebih mendominasi kelas dan siswa lebih cenderung menerima, akibat proses pembelajaran menjadi tidak bermakna dan bersikap negatif terhadap matematika.

Keadaan ini tidak sesuai seperti yang dikehendaki dalam Kurikulum 2013, yang mana siswa dituntut peran aktifnya dalam membangun sendiri pengetahuan yang dipelajari untuk mencapai tujuan pembelajaran. Hudojo (Nurahini \& Wahyuni, 2006) menjelaskan mengajar matematika dalam pandangan konstruktivistik bukan lagi mentransfer pengetahuan. Mengajar matematika adalah memberikan dan menata pengetahuan matematika. Pengalaman siswa sendiri dan refleksi terhadap pengalaman tersebut yang merupakan kunci dalam belajar bermakna. Seseorang dikatakan telah belajar matematika kalau dia mengalami sendiri kegiatan-kegiatan matematika.

Salah satu model pembelajaran yang dapat digunakan untuk memperbaiki hasil belajar siswa adalah model pembelajaran kooperatif tipe TAI. Slavin (2016) menjelaskan bahwa TAI merupakan salah satu model pembelajaran kooperatif yang menarik karena menerapkan gabungan dari dua hal, yaitu belajar dengan kemampuan masing-masing individu dan belajar kelompok. Dengan pembelajaran tipe TAI tersebut, guru dapat meningkatkan kemampuan berpikir kritis dan aktivitas siswa untuk menjadi lebih aktif. Hal ini terlihat dari penelitian yang dilakukan oleh Karim dan Anshariyah (2016) yang menunjukkan bahwa menunjukkan bahwa model pembelajaran kooperatif tipe TAI dapat melatih kemampuan pemecahan masalah matematis siswa sehingga dapat meningkatkan kemampuan berpikir kritis siswa.

Wenno (2014) mengemukakan beberapa perlunya menggunakan model pembelajaran kooperatif tipe TAI untuk dikembangkan sebagai variasi pembelajaran agar hasil belajar dapat tercapai, antara lain adalah dalam model pembelajaran ini tidak ada persaingan antar siswa kerena siswa saling bekerja sama untuk menyelesaikan masalah dalam mengatasi cara berpikir yang berbeda, siswa tidak hanya mengharapkan bantuan dari guru, tetapi siswa juga memotivasi untuk belajar cepat dan akurat pada seluruh materi dan guru setidaknya hanya menggunakan setengah dari waktu mengajarnya sehingga akan lebih mudah dalam pemberian bantuan secara individu.

Model pembelajaran TAI memiliki delapan komponen (Slavin, 2016). Kedelapan komponen tersebut adalah sebagai berikut : (1) Teams, yaitu pembentukan kelompok heterogen yang terdiri atas 4 sampai 5 siswa. (2) Placement test, yakni pemberian pretest 
kepada siswa atau melihat rata-rata nilai harian siswa agar guru mengetahui kelemahan siswa pada bidang tertentu. (3) Student creative, melaksanakan tugas dalam suatu kelompok dengan menciptakan situasi di mana keberhasilan individu ditentukan atau dipengaruhi oleh keberhasilan kelompoknya. (4) Team study, yaitu tahapan tindakan belajar yang harus dilaksanakan oleh kelompok dan guru memberikan bantuan secara individual kepada siswa yang membutuhkannya. (5) Team scores and team recognition, yaitu pemberian skor terhadap hasil kerja kelompok dan memberikan kriteria penghargaan terhadap kelompok yang dipandang kurang berhasil dalam menyelesaikan tugas. (6) Teaching group, yakni pemberian materi secara singkat dari guru menjelang pemberian tugas kelompok. (7) facts test, yaitu pelaksanaan tes-tes kecil bardasarkan fakta yang diperoleh siswa. Dan (8) whole class units, yaitu pemberian materi oleh guru kembali di akhir waktu pembelajaran dengan strategi pemecahan masalah

Penerapan model pembelajaran kooperatif tipe TAI cocok dengan materi himpunan, karena model ini dapat dikembangkan dengan cara melibatkan aktifitas siswa dalam pembelajaran serta membantu siswa dalam mempelajari konsep dan menerapkannya dalam kehidupan sehari-hari. Intisari dari belajar kooperatif Team Assited Individualization (TAI) adalah bahwa otak tidak menerima informasi dengan pasif, melainkan justru dengan aktif mengkonstruksi suatu interpretasi dari informasi tersebut dan kemudian membuat kesimpulan.

\section{METODE PENELITIAN}

Penelitian ini adalah penelitian eksperimen dengan desain kelompok kontrol pasca tes (posttest-only control group design). Materi yang diajarkan adalah himpunan dan operasinya. Secara umum, desain penelitian menurut Sugiyono (2014) dapat diskemakan sebagaimana disajikan pada Tabel 1.

Tabel. 1. Desain Penelitian

\begin{tabular}{lcc}
\multicolumn{1}{c}{ Kelompok } & Perlakuan & Postes \\
\hline Eksperimen & $\mathrm{O}_{1}$ & $\mathrm{~T}$ \\
Kontrol & $\mathrm{O}_{2}$ & \\
\hline Keterangan: & \\
$\mathrm{O}_{1}$ : Penerapan Pembelajaran Kooperatif Tipe TAI \\
$\mathrm{O}_{2}:$ Penerapan Pembelajaran Model Konvensional
\end{tabular}


Populasi dalam penelitian ini adalah siswa kelas VII di SMP Maria Mediatrix Ambon dengan sampel yang dipilih sebanyak dua kelas, satu kelas dipilih sebagai kelas eksperimen yang menggunakan pembelajaran kooperatif tipe TAI, sedangkan kelas lainnya sebagai kelas kontrol yang menggunakan model konvensional. Teknik pengambilan sampel yang dilakukan dalam penelitian ini adalah dengan menggunakan cara purposive sampling, dengan pertimbangan kelas yang memiliki kemampuan awal yang sama (yang ditunjukkan dengan nilai tes pada materi sebelumnya).

Variabel yang digunakan yaitu hasil belajar matematika siswa yang diajarkan dengan model pembelajaran kooperatif tipe TAI $\left(\mathrm{X}_{1}\right)$ dan hasil belajar matematika siswa yang diajarkan dengan model pembelajaran Konvensional $\left(\mathrm{X}_{2}\right)$. Data kuantitatif yang dikumpulkan dianalisis menggunakan SPSS 20 untuk menguji beda rata-rata (uji t) tapi sebelumnya dilakukan uji prasyarat yaitu uji normalitas dan uji homogenitas

\section{HASIL DAN PEMBAHASAN}

Dua kelas yang dipilih memiliki kemampuan awal yang hampir sama yang diperoleh dari nilai rata-rata tes harian untuk materi sebelumnya, seperti pada Tabel 2.

Tabel 2. Rata-rata Nilai Ulangan Harian Sebelum Eksperimen

\begin{tabular}{lc}
\hline \multicolumn{1}{c}{ Kelas } & Rata-rata \\
\hline Eksperimen & 73,88 \\
Kontrol & 73,53 \\
\hline
\end{tabular}

Nilai awal yang digunakan menujukkan bahwa kemampuan siswa pada kelas eksperimen dan kontrol tergolong sama karena selisih rata-rata kedua kelas hanya 0,35. Pembelajaran dilakukan sebanyak 4 kali pertemuan dan pada pertemua kelima dilakukan tes akhir untuk melihat efektifitas model pembelajaran TAI. Hasil tes akhir untuk kedua kelas dapat dilihat pada Tabel 3.

Tabel 3. Hasil Belajar Siswa

\begin{tabular}{lccc}
\hline \multirow{2}{*}{ Kualifikasi } & \multirow{2}{*}{ Hasil Belajar } & \multicolumn{2}{c}{ Persentase Siswa (\%) } \\
\cline { 3 - 4 } & & Kelas Eksperimen & Kelas Kontrol \\
\hline Baik sekali & $80-100$ & 40 & 15 \\
Baik & $66-79$ & 30 & 25 \\
Cukup & $55-65$ & 15 & 15 \\
Kurang & $46-54$ & 5 & 15 \\
Gagal & $\leq 45$ & 10 & 30 \\
\hline
\end{tabular}

Keterangan: Kriteria berdasarkan KKM sekolah 
Berdasarkan data pada Tabel 3, terlihat bahwa pada kelas eksperimen terdapat $70 \%$ siswa berada pada kualifikasi baik dan baik sekali, 20\% siswa yang berada pada kualifikasi cukup dan kurang dan hanya 10\% siswa yang gagal. Sedangkan pada kelas kontrol hanya 40\% yang memiliki kualifikasi baik sekali dan baik, 30\% memiliki kualifikasi cukup dan kurang dan 30\% siswa yang gagal. Ini menunjukkan bahwa persentase siswa yang gagal pada kelas kontrol jauh lebih besar daripada kelas eksperimen. Lebih dari setengah siswa pada kelas eksperimen memiliki kualifikasi baik dan baik sekali, berbeda dengan kelas kontrol yang tidak mencapai 50\%. Hasil ini dapat dijelaskan dalam diagram batang pada Gambar 1.

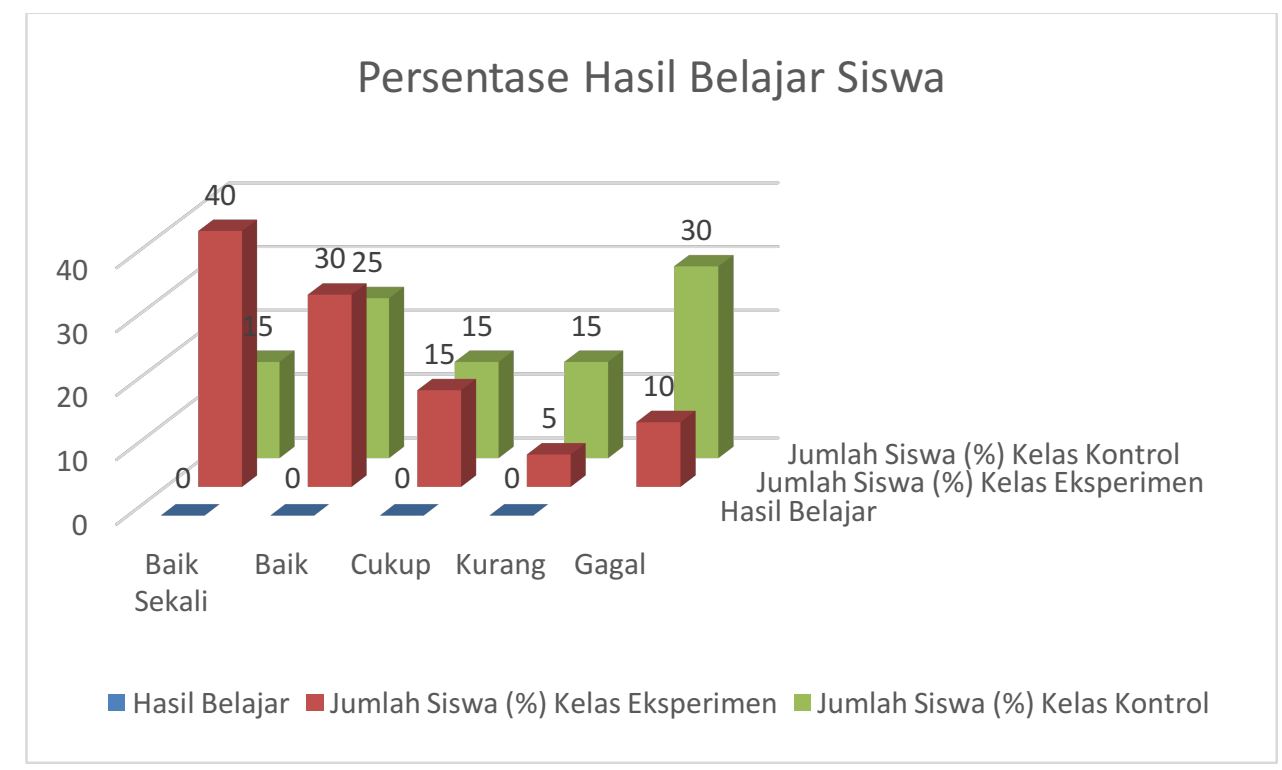

\section{Gambar 1. Distribusi Hasil Belajar}

Sebelum melakukan uji-t untuk melakukan pengujian terhadap efektifitas model pembelajaran koopertif tipe TAI, terlebih dahulu dihitung nilai rata-rata hasil belajar kedua kelas. Rata-rata tes hasil belajar untuk kedua kelas masing-masing seperti Tabel 4.

Tabel 4. Rata-rata Nilai Nilai Tes Hasil Belajar

\begin{tabular}{lc}
\multicolumn{1}{c}{ Kelas } & Rata-rata \\
\hline Eksperimen & 67,75 \\
Kontrol & 54,45 \\
\hline
\end{tabular}

Dalam rangka untuk mengetahui, apakah rata-rata tersebut berbeda secara signifikan pada taraf signifikan 5\%, maka dilakukan uji beda rata-rata (Uji-t). Namun sebelum melakukan uji t, dilakukan uji prasyarat terlebih dahulu, yaitu uji normalitas dan homogenitas. Dalam rangka untuk mengetahui normal tidaknya distribusi dari data 
populasi, maka dilakukan perhitungan Chi-Kuadrat untuk kelas eksperimen dan kelas kontrol dan diperoleh hasil seperti pada Tabel 5.

Tabel 5. Hasil Uji Normalitas $(\alpha=0.05)$

\begin{tabular}{lcc} 
& Kelas Kontrol & Kelas Eksperimen \\
\hline Chi-Square & $2,400^{\mathrm{a}}$ & $6,400^{\mathrm{b}}$ \\
df & 13 & 11 \\
Asymp. Sig. & 0,999 & 0,845 \\
\hline
\end{tabular}

Berdasarkan Tabel 5, tampak bahwa pada kelas eksperimen, diperoleh nilai Sig. lebih besar dari nilai $\propto=0,05$ yaitu 0,845 . Hal serupa juga nampak pada kelas kontrol, nilai Sig. lebih besar dari nilai $\propto=0,05$, yakni 0,999 . Hal ini berarti bahwa berdasarkan data yang diperoleh, tidak terdapat cukup bukti untuk menolak $\mathrm{H}_{\mathrm{O}}$. Dengan demikian dapat disimpulkan bahwa data penelitian yang diambil adalah sampel yang berasal dari populasi yang berdistribusi normal.

Lebih lanjut, berdasarkan hasil uji Levene, dengan menggunakan software SPSS 20 for Windows, diperoleh hasil sebagaimana disajikan pada Tabel 6.

Tabel 6. Hasil Uji Homogenitas

\begin{tabular}{lccccc}
\hline & Sum of Square & Df & Mean Square & F & Sig. \\
\hline Between Groups & 1721,628 & 2 & 860,814 & 3,317 & 0,076 \\
Within Groups & 23250,215 & 85 & 273,532 & & \\
Total & 24971,842 & 87 & & & \\
\hline
\end{tabular}

Berdasarkan hasil analisis pada Tabel 6, terlihat bahwa nilai Sig. lebih besar dari nilai $\propto=0,05$ yakni 0,076 . Hal ini berarti bahwa berdasarkan data yang diperoleh, tidak terdapat cukup bukti untuk menolak $\mathrm{H}_{0}$. Dengan demikian dapat disimpulkan bahwa varians kedua kelas adalah homogen, artinya kemampuan siswa kedua kelas sesudah diberikan perlakuan adalah homogen. Berdasarkan hasil analisis tersebut, maka analisis data menggunakan uji-t dapat dilakukan.

Lebih lanjut, setelah diketahui melalui uji prasyarat bahwa sampel yang diambil dinyatakan normal dan homogen, maka selanjutnya uji hipotesis dilakukan dengan menggunakan uji perbedaan rata-rata atau uji-t diperoleh hasil sebagai mana disajikan pada Tabel 7. 
Tabel 7. Hasil Uji Rata-rata

\begin{tabular}{llll}
\hline Nilai & t hitung & df & Sig (2 tail) \\
\hline Kelas Kontrol dan Kelas Eksperimen & 2,206 & 38 & 0,033 \\
\hline
\end{tabular}

Berdasarkan Tabel 8, terlihat bahwa nilai Sig. (2-tailed) lebih kecil dari nilai $\propto=$ 0,05 yakni 0,033 . Hal ini menunjukan bahwa pada taraf signifikan $\propto=5 \%, \mathrm{H}_{\mathrm{O}}$ ditolak. Dengan demikian dapat disimpulkan bahwa terdapat perbedaan efektivitas antara pembelajaran TAI dan pembelajaran pada kelas kontrol yang diajarkan dengan menggunakan model pembelajaran konvensional.

Pelaksanaan penelitian ini dengan menggunakan dua kelas, yaitu kelas eksperimen dan kelas kontrol. Kelas eksperimen adalah kelas $\mathrm{VII}_{1}$ menggunakan model pembelajaran TAI, sedangkan kelas kontrol adalah kelas $\mathrm{VII}_{3}$ menggunakan model pembelajaran konvensional, yang kemudian akan dilihat perbedaan hasil belajar dari kedua sampel kelas tersebut.

Pemberian perlakuan yang berbeda pada kedua kelas tersebut memberikan hasil akhir yang berbeda pula. Hal ini tampak pada perbedaan nilai rata-rata hasil belajar siswa yakni untuk kelas yang diajarkan dengan model pembelajaran TAI memperoleh nilai ratarata 67,75 lebih tinggi dari kelas yang diajarkan dengan model pembelajaran konvensional yang hanya memperoleh nilai rata-rata 54,45.

Setelah memperoleh hasil tes akhir dari kedua kelas, maka dilakukan perhitungan statistik untuk mengetahui ada tidaknya perbedaan hasil belajar melalui uji perbedaan rata-rata dengan menggunakan uji-t. Hasil dari uji-t menunjukkan bahwa nilai $t_{\text {hitung }}=$ 2,9039 lebih besar dari nilai $t_{\text {tabel }}=2,02439$ dan nilai Sig.(2-tailed) lebih kecil dari nilai $\propto=0,05$ yakni 0,033 , sehingga dapat disimpulkan bahwa terdapat perbedaan hasil belajar siswa yang diajarkan dengan model pembelajaran Team Assited Individualization (TAI) dan hasil belajar siswa yang diajarkan dengan menggunakan model pembelajaran konvensional pada materi himpunan.

Model pembelajaran kooperatif dengan tipe TAI lebih efektif terhadap hasil belajar himpunan disebabkan beberapa hal:

- Pada kelas eksperimen siswa menggunakan bahan ajar dan LKS yang disiapkan guru sehingga siswa memiliki sumber informasi selain buku siswa. LKS juga 
menolong siswa menyelesaikan masalah-masalah yang diberikan sehingga siswa memiliki kemampuan yang baik terhadap materi yang diberikan.

- Pada kelas eksperimen siswa bekerja secara individu kemudian diskusi dalam kelompok siswa. Menurut Slavin (2016) TAI mengombinasikan keunggulan pembelajaran kooperatif dan pembelajaran individual. Oleh karena itu kegiatan pembelajarannya lebih banyak digunakan untuk pemecahan masalah. Dengan memperhatikan dan membimbing siswa selama bekerja dalam kelompok dengan cara aktif bertanya kepada tiap siswa tentang apa yang telah dikerjakannya dalam kelompok, dengan begitu siswa akan lebih termotivasi untuk aktif dalam menyelesaikan tugas kelompok.

- Persentase kelompok mendorong terjadinya diskusi kelas sehingga 'memaksa' siswa mempersiapkan diri secara kelompok sebaik mungkin. Siswa dapat berperan aktif dalam proses pembelajaran, sehingga siswa mampu bekerja dalam kelompok dan berani mengajukan pertanyaan yang diajukan dari masing-masing kelompok, hal ini berdampak pada peningkatan hasil belajar siswa yang diajukan oleh hasil tes akhir yang dilakukan. Siswa dapat belajar dari lainnya serta mempunyai kesempatan untuk membelajarkan siswa yang lain, karena pada pembelajaran kooperatif keberhasilan kelompok sangat diperhatikan, maka siswa yang pandai ikut bertanggung jawab membantu temannya yang lemah dalam kelompoknya (Slavin, 2016)

- Guru tidak menjadi sumber utama, guru hanya bertindak sebagai fasilitator untuk menolong siswa mengonstruksi sendiri pengetahuannya. Seperti yang dikemukakan Sardiman (2011) peran guru sebagai pembimbing harus berusaha menghidupkan dan memberikan motivasi agar terjadi proses interaksi yang kondusif. Hal ini sejalan dengan pendapat Ratumanan (2015) bahwa peran guru dalam mengorganisasikan kelompok dalam kegiatan belajar mengajar serta memfasilitasi siswa dalam belajar menjadi salah satu kunci keberhasilan siswa.

- Penghargaan kelompok menjadi penyemangat bagi siswa untuk tampil dengan baik dan berlomba-lomba menjawab pertanyaan dengan benar.

- Terdapat tes-tes kecil berdasarkan materi pembelajaran yang memberikan kesempatan pada siswa untuk mengevaluasi kemampuan mereka di akhir pembelajaran dan memperbaiki kesalahan mereka 
Hal yang berbeda terjadi pada kelas kontrol. Guru mendominasi pembelajaran dengan menjelaskan materi sedangkan siswa banyak mencatat dan menempatkan diri sebagai pendengar saja. Guru membangun pengetahuan siswa dengan menjelaskan materi secara bertahap, memberikan contoh kemudian menjelaskannya, dan memberikan kesempatan pada siswa untuk bertanya pada setiap materi yang dijelaskan. Jainuri (2008) menyatakan bahwa dalam model konvensional, guru memegang peran utama dalam menentukan isi dan urutan langkah dalam penyampaian materi tersebut kepada siswa.

Hal ini menimbulkan kebosanan pada diri siswa dan mereka cenderung mencari kesibukan sendiri. Ratumanan (2015) mengatakan bahwa proses transfer informasi menjadi kondisi yang dominan dalam model pembelajaran konvensional. Siswa diposisikan sebagai objek dalam kegiatan belajar mengajar dan pasif dalam menerima informasi atau pengetahuan yang disampaikan guru. Guru ditetapkan sebagai sumber utama pengetahuan dan berfungsi sebagai pentransfer pengetahuan, sebaliknya siswa lebih banyak pasif.

\section{SIMPULAN}

Berdasarkan hasil dan pembahasan dalam penelitian ini maka dapat disimpulkan bahwa terdapat perbedaan efektivitas antara model pembelajaran Team Assited Individualization (TAI) dan Model Pembelajaran Konvensional. Hasil belajar siswa kelas VII SMP Maria Mediatrix Ambon yang diajarkan dengan model pembelajaran kooperatif tipe TAI lebih tinggi dibandingkan hasil belajar siswa yang diajarkan dengan menggunakan model pembelajaran konvensional, khususnya pada materi himpunan.

\section{DAFTAR RUJUKAN}

Adilistiyo, M.E. (2017). Analisis Kesalahan Siswa SMP Kelas VII dalam Menyelesaikan Soal Pada Materi Himpunan. Naskah Publikasi. Surakarta: Universitas Muhammadiyah Surakarta.

Arfiyanti, D., Irawan, E.B., dan Purwanto. (2017). Peningkatan Pemahaman Konsep Himpunan Melalui Mind Mapping Kelas VII SMP. Jurnal Pendidikan: Teori, Penelitian, dan Pengembangan. 2 (6), 799-805.

Jainuri, M. (2008). Pembelajaran Konvesional. Yogyakarta: Pustaka Belajar.

Nurahini, D. dan T. Wahyuni. (2006). Matematika Konsep dan Aplikasinya: Untuk SMP/MTs Kelas VII. Jakarta: Pusat Perbukuan.

Karim dan A. Anshariyah. (2016). Penerapan Model Pembelajaran Kooperatif Tipe Team 
Assisted Individualization (TAI) untuk Melatih Kemampuan Pemecahan Masalah Matematis Siswa SMA, EDU-MAT Jurnal Pendidikan Matematika, 4(1), 58-67.

Khairul, T. (2018). Analisis Strategi Pemecahan Masalah Matematika Siswa Pada Materi Himpunan Di Kelas VII MTsN 2 Aceh Besar. Skripsi. Banda Aceh: Universitas Islam Negeri Ar-Raniry Darussalam.

Pratiwi, W. N. F. (2016). Analisis Kesulitan Belajar Siswa Pada Materi Himpunan Di SMP Muhammadiyah 10 Surakarta Tahun Pelajaran 2015/2016. Naskah Publikasi. Surakarta: Universitas Muhammadiyah Surakarta.

Ratumanan, T. G. (2015). Inovasi Pembelajaran, Mengembangkan Kompetensi Peserta Didik Secara Optimal. Yogyakarta: Ombak.

Sardiman, A. M. (2011). Interaksi dan Motivasi Belajar Mengajar. Jakarta: PT. Rajagrafindo.

Slavin, R.E. (2016). Cooperative Learning Teori, Riset dan Praktik. Bandung: Nusa Media.

Sugiyono. (2014). Metode Penelitian Pendidikan: Pendekatan Kuantitatif, Kualitatif dan $R \& D$. Bandung: Alfabeta.

Wenno, C. Z. (2014). Peningkatan Hasil Belajar Siswa SMP Negeri 3 Ambon Pada Materi Operasi Hitung Bentuk Aljabar Dengan Menggunakan Model Pembelajaran Kooperatif Tipe Team Assisted Individualization (TAI). Skripsi. Ambon: Universitas Pattimura. 